\title{
THE \\ The Emergence of Equity Investment Jan in Developing Countries: Overview
}

\author{
Stijn Claessens
}

Equity flows to developing countries have increased sharply in recent years. Foretgn equity investment can be benefictal to developing countries because of its risk-sharing characteristics and effects on resource mobilization and allocation. Empirical evidence shows that the stock markets of developing countries have become more, although not fully, integrated with world financial markets, and this increased integration implies a lower risk-adjusted cost of capital. Constraints to further increasing the flows and expanding the benefits are macroinstability, poorly functioning stock markets, and insufficiently open financial markets. Empirical evidence does not support the view that equity flows are more volatile than other types of capttal flows or that equity flows have a negative impact on the volatility of stock prices.

World financial markets in recent years have been characterized by trends toward increased integration, securitization, and liberalization. Financial markets today show a much higher degree of integration, with large amounts of capital flowing across borders to take advantage of the slightest perceived financial or diversification benefit. Gross capital flows among industrial countries are also much larger now than a decade ago. Gross capital outflows from the main industrial countries came to about $\$ 850$ billion in 1993 , compared with an average of about $\$ 500$ billion during $1985-93$ and about $\$ 100$ billion in the first half of the 1980s (Bank for International Settlements 1993/1994, p. 148). Much of this increased cross-border flow has been in the form of easily tradable securities-bonds, equities, and other negotiable instruments. All of this has happened against a background of increased liberalization of domestic financial markets and an opening up of markets to foreigners as capital controls and other barriers have been removed, especially in developing countries.

Buttressed by improved domestic policies and increased economic growth, developing countries have shared in these trends. Total net capital flows (in real

Stıjn Claessens is with the Technical Department of the Europe and Central Asıa and Middle East and North Africa Regions at the World Bank. He thanks Geert Bekaert, Elane Buckberg, Asli DemirguçKunt, Campbell Harvey, Leonardo Hernandez, and Andrew Warner for useful comments. The artucle draws partly on joint work with Sudarshan Gooptu. Part of this research was funded by World Bank research grants RPO 678-01 and 679-94.

(C) 1995 The International Bank for Reconstruction and Development/THE WORLD BANK 
terms) to all develaping countries have in recent years reached their highest level since the debt crisis of the early 1980s (World Bank 1993). In particular, private capital flows have sharply increased in the 1990 s and are now about 50 percent higher than they were at their peak in the early 1980 s. In comparison with the late 1970 s, when there were also large private flows, there has been a shift among private flows from bank to nonbank sources through increased direct and portfolio investment. ${ }^{1}$ Direct investment flows to developing countries have been increasing at very high rates since the mid-1980s. More recently, portfolio flows (bonds, certificates of deposit, commercial paper, and equity) to developing countries have increased sharply in magnitude, especially to the so-called emerging markets. ${ }^{2}$ Equity portfolio flows have been an important component of these portfolio flows.

The large amount of portfolio flows to several developing countries has raised a number of policy and research questions. What benefits does an investor in an industrial country gain from investing in these markets? How well are these developing countries financially integrated with the markets of industrial countries? How has this changed over time? To what extent is financial integration a function of changes in barriers to free capital movements? What exactly are these barriers (in developing countries as well as industrial countries)?

Other questions have also been raised: What is the volume of financing that can be expected from portfolio flows in the coming years, to which countries will the flows go, and from which investors will the flows come? To what extent are these flows a function of factors in the developing countries and factors in the industrial countries? Are these flows volatile ("hot money"), and do they perhaps call for some form of public action? Do the stock markets in these countries price securities efficiently? What is the broader role of stock markets in resource allocation and managerial control? What is the relation between stock market development and domestic economic performance?

These are the types of questions addressed in this issue, which includes six articles that were presented at a World Bank Conference on Portfolio Investment in Developing Countries in September 1993 (for the conference proceedings, see Claessens and Gooptu 1993). This overview presents the context for and summarizes the main results of the six articles. Where useful, the overview provides a short summary of relevant literature and the results of related papers. It should be kept in mind that this research presents the first wave of serious research on this topic. Many questions are not answered exclusively; more experience and

1. As a percentage of exports or of the gross domestic product (GDP) of developing countries, total aggregate resource flows in the $1990 \mathrm{~s}$, although much above their level in the mid-1980s, are still below their level in the mid- to late 1970 s. Compared with that in the 1970 s, the recent increase in flows reflects more a change in composition than an increase in overall net flows. In the 1970 s, most financing was from commercial banks (to governments), and equity investment (both portfolio and direct) was a much smaller percentage than today.

2. Emerging markets are commonly considered to be those markets represented in the IFC's Emerging Markets Data Base (EMDB), currently twenty-five markets. 
research on this important aspect of international capital markets will be necessary in the coming decade.

Section I provides a short overview of the amounts of and motivation for equity portfolio flows. Section II provides an overview of different approaches to testing for benefits of equity investment in developing countries from an investor point of view and summarizes the most important empirical findings. Section III discusses the role of stock markets and the benefits from equity investment for developing countries. Section IV discusses the various policy issues for developing countries that can arise from increased equity (and other portfolio) flows. Section V summarizes the findings.

\section{The Amounts of and Motivation for Equity Portfolio Flows}

From 1989 to 1993 total portfolio flows (bonds, certificates of deposit, commercial paper, and equity) increased more than sevenfold to a level of $\$ 55.8$ billion (see table 1 and Gooptu 1993). Portfolio flows now account for about a third of overall net resource flows to developing countries. Equity flows have been an important component of these portfolio flows. Total equity flows to developing countries were $\$ 13.2$ billion in 1993 , quadruple that of three years earlier. Even though small for developing countries on aggregate (about 7 percent of the aggregate net resource flows they received in 1993), equity flows are an important source of external finance for some developing countries (for example, equity flows represented about a quarter of the total net external financing of Mexico in 1991 and 1992).

Equity flows have taken several forms: direct equity purchases by investors in the host stock markets; investments through country funds; issues of rights on equities held by depository institutions in the form of American Depository Receipts (ADRs) and Global Depository Receipts (GDRs); ${ }^{3}$ and direct foreign equity offerings. In the early 1990 s equity flows have largely taken place through depository receipts. For 1989-93 the volume of ADRS and GDRs issued for equity claims on developing countries is estimated to have been about $\$ 18.2$ billion (table 1), including direct offerings on foreign capital markets by corporations in developing countries outside the ADR or GDR structure (under Rule $144 \mathrm{~A}$ in the United States). Until 1990 most important were (closed-end) country funds: during 1989-93 new country funds were created for developing countries with an aggregated size of $\$ 10.3$ billion. The highest relative increase in the early 1990s has been in direct purchases of equities: these are estimated to have been about $\$ 3.2$ billion in 1993 , up from $\$ 0.8$ billion in 1990 , and were second in importance during 1989-93.

3. ADRS and GDRS are receipts issued by financial intermediaries in industrial countries against shares held in custody by these intermediaries in the developing countries. 
Table 1. Portfolio Flows to Developing Countries, 1989-93

(estimates in billions of U.S. dollars)

\begin{tabular}{lrrrrrr}
\hline Type of flow & 1989 & 1990 & 1991 & 1992 & $1993 \mathrm{a}$ & $\begin{array}{c}\text { Total } \\
1989-93 \mathrm{a}\end{array}$ \\
\hline Bonds, commercial paper, and & & & & & & \\
$\quad$ certificates of deposit & 4.0 & 5.5 & 12.7 & 23.7 & 42.6 & 88.5 \\
Equity & 3.5 & 3.8 & 7.6 & 13.0 & 13.2 & 41.1 \\
New country funds & 2.2 & 2.9 & 1.2 & 1.3 & 2.7 & 10.3 \\
American and global deposit & & & & & & \\
$\quad$ receipts & 0.0 & 0.1 & 4.9 & 5.9 & 7.3 & 18.2 \\
Direct equity & 1.3 & 0.8 & 1.5 & 5.8 & 3.2 & 12.6 \\
$\quad$ Total & 7.5 & 9.3 & 20.3 & 36.7 & 55.8 & 129.6 \\
\hline
\end{tabular}

a. Estimated for 1993.

Source: World Bank (1993).

Various factors in both developing and industrial countries have played a role in the increased importance of equity flows in recent years. An important factor has likely been the decline in global interest rates in the early 1990 s, which was an important "push" for equity flows (Calvo, Leiderman, and Reinhart 1993; Dooley, Fernandez-Arias, and Kletzer 1994; Fernandez-Arias 1994). But there is no doubt that the increase in these flows is partly also motivated by improved domestic policies and better growth performance in the recipient countries, reflected in higher rates of return on equity (Chuhan, Claessens, and Mamingi 1993).

Another contributing factor has been the removal of barriers by developing and industrial countries on foreign participation in developing countries' stock markets (Claessens and Rhee 1994). Many developing countries have removed restrictions on foreign ownership, liberalized capital account transactions, improved their accounting and information standards, and in general made it easier for foreigners to access their markets. Particularly in Europe and Latin America, many countries now have very few or no restrictions on access by foreigners to their markets and treat foreign and domestic investors almost identically (see IFC various years). Similarly, several industrial countries have removed or relaxed their restrictions on investments in developing countries (Chuhan 1994).

\section{BENEFITS FOR INVESTORS}

The benefits for an investor of equity investment in emerging markets ultimately depend on a tradeoff between the expected rate of return and its associated risk. To assess this tradeoff a number of factors are important: the underlying factors driving the rate of return and its variability; the efficiency of the domestic stock market; the regulatory, accounting, and enforcement standards in the host country; the ability to invest in the country; the different forms of transfer risk (for example, the possibility that capital controls will be imposed, affecting the ability to repatriate capital out of the host country); taxes and other 
transaction costs; and restrictions and regulatory and accounting standards imposed on investors in the home country (for example, restrictions on the share of foreign assets held by pension funds).

Returns on emerging stock markets have been high. For example, the annual U.S. dollar rate of return on the IFC composite index for Latin America was 38.88 percent during $1988-93$, compared with 14.40 percent for the U.S. Standards and Poor 500. The volatility of U.S. dollar rates of return has, however, also been high. For example, it was as high as 100 percent on an annual basis for Argentina during the same period. The high ex post rates of return and high volatility already suggest a tradeoff from the investor's point of view.

The risk-return tradeoff should, however, be investigated from the point of view of an internationally well-diversified investor who is considering investing in emerging markets. Because correlations between equity returns from different countries are lower than those between equity returns in the same country, the benefits of diversification-a lower risk for equivalent return or a higher return for equivalent risk-are stronger across international financial markets than within domestic markets. This is especially true for investments in developing countries, because their stock returns tend to have (even) lower correlations with those of industrial countries. Participation in developing countries is thus likely to lower overall unconditional portfolio risk. This fact is by now well established. Harvey (1993) and Divecha, Drach, and Stefak (1992), for example, find that by investing up to about 20 percent of an international portfolio in developing countries, the risk-return tradeoff can be Pareto-improved, in which case the unconditional mean-variance frontier shifts dramatically upwards. Harvey (1994) and De Santis (1993) show that this upward shift is not only dramatic but also statistically significant.

The important caveat concerning these diversification benefits is whether these gains are attainable. Barriers may restrict investment in these markets. (Another caveat is, of course, transaction costs.) The benefits of diversification relate then also to the degree of capital-market integration. Without barriers, capital markets tend to be fully integrated; financial assets traded in different markets but with identical risk characteristics will yield identical expected returns. Alternatively, with barriers, markets tend to be segmented, and assets in different markets may have different expected returns even when their risk characteristics are the same.

\section{Ways to Test for and Measure Stock Market Segmentation}

There are several ways to test for and measure the degree of stock market segmentation. One way is to explicitly model the barriers, derive the effect on equilibrium asset prices and stock holdings, and then test the model. (See Stulz 1994, for example, for a review of the equilibrium pricing given ownership restrictions, taxes, or other barriers.) This approach is difficult, however, because there are many barriers to consider, and few of them can be easily quantified. In any case, using a specific asset-pricing model entails the risk of mis- 
specification, because it is unclear whether rejections should be attributed to the model or to lack of integration.

Another way to test for and measure stock market integration is to assume that market integration exists and that a particular asset-pricing model holds. This method also risks misspecification and is hampered by the lack of a wellestablished international asset-pricing model. The single-factor Capital Asset Pricing Model (CAPM) with one source of risk is often used in a domestic context. This model cannot be applied to international stock market returns because it can describe international stock market returns only if all investors have identical preferences (see Solnik 1974 and the review by Adler and Dumas 1983). Unless purchasing power parity holds-which it does not in the short runexchange risk will have to enter the tests. Few modern empirical tests have done so, however (recent exceptions are Dumas and Solnik 1994 and Ferson and Harvey 1993). In general, empirical results have been ambiguous in tests of the international CAPM (see Stulz 1994 and Dumas 1994 for reviews).

Although a fully satisfying asset-pricing model is lacking, the general direction in empirical tests has been toward more complex, multifactor models. Here, risk is measured with respect to the covariances, that is "betas," of equity returns with various risk factors. Because risk factors need to be prespecified, this approach also runs the risk of misspecification.

A related further complication is that recent research has found significant time variation in expected returns, both domestic and international, but no consensus has emerged on what drives this apparent predictability. (A simple, static asset-pricing model would imply no changes over time in the predictability of returns.) It is unclear whether the predictability of returns itself is evidence of market inefficiency, time-varying risk premiums, or infrequent trading of stocks (see Harvey 1995). Without an explicit, dynamic asset-pricing theory, it is impossible to distinguish between highly variable risk premiums, peso problems, regime switches, knowledge of policy changes, or other inefficiencies. Nevertheless, it has been found that returns in different industrial countries can be predicted by using a common set of instruments (for example, Harvey 1991). This commonality suggests that industrial countries are relatively well integrated. Thus, a third way to measure integration is to test for any commonality in the factors driving the predictability of returns across countries.

A fourth way to measure integration is to look at actual investment patterns. Actual portfolios of investors in industrial countries exhibit significant "home bias"; that is, the shares of domestic securities in the portfolios are much higher than one would expect on the basis of risk-return tradeoffs and a reasonable level of risk aversion, and this suggests a lack of integration (French and Poterba 1991; Tesar and Werner forthcoming). ${ }^{4}$

4. Admittedly, the asset-allocation model used to derive the optimal shares could be misspecified. Possibly, differences in consumption baskets, deviations from purchasing power parity, uninsurable (nontradable) income risk, and borrowing constraints could explain this home bias. French and Poterba 


\section{Evidence of Integration}

The difficulties associated with testing for and measuring stock market integration have motivated some of the authors in this issue (Bekaert, Buckberg, Harvey, and Tesar and Werner) to pursue various approaches (for related work see De Santis 1993 and Bekaert and Harvey 1994).

Bekaert and Harvey use the world portfolio as a benchmark for measuring risk. They report that an unconditional, single-factor CAPM is unable to characterize returns in emerging markets. This result confirms-actually as a corollary-the unconditional mean-variance diversification benefits already mentioned. Tests for diversification benefits and lack of integration are identical if one (global) source of risk is assumed. Deviations from integration amount, then, to unexploited (mean-variance) diversification benefits and diversification benefits imply lack of integration.

Bekaert observes, however, that the slope coefficient of the country return on the world portfolio return (beta) has increased for most emerging markets in recent years. He interprets these higher betas as signs of increased integration, because most industrial countries have high betas. Buckberg goes a step further by testing a conditional, single-factor CAPM in which expected returns are allowed to change over time. In contrast to Bekaert and Harvey, Buckberg cannot reject that emerging equity markets were integrated in more recent years, whereas she could reject it for the earlier period, and this suggests that the benefits of further diversifying into emerging markets have been reduced. However, Harvey questions the power of the test Buckberg uses. Harvey (1994) allows both expected returns as well as covariance risk (beta) to change over time and finds that this more general model is rejected.

Harvey tests multifactor models and finds significant evidence that global risk factors are not powerful in explaining returns in emerging markets, especially compared with explaining returns in industrial countries. His evidence is consistent with emerging markets' being segmented from industrial countries. $\mathrm{He}$ finds, however, that compared with earlier periods, the importance of global factors for many emerging markets has increased, suggesting greater, but still imperfect, integration.

Bekaert investigates the degree of predictability of rates of return in emerging markets using both global and domestic variables (see also Buckberg 1993 and Harvey 1994). He finds that rates of return in the emerging markets are more predictable than in industrial countries, mostly because of the higher autocorrelation of returns in emerging countries. Bekaert finds that global instruments

(1991) and Tesar and Werner (forthcoming) provide some further explanations. Cooper and Kaplanis (1991) provide some evidence, however, that the magnitude of the home bias cannot be explained by differences in consumption baskets or deviations from purchasing power parity alone. Purchasing power parity deviations combined with deadweight costs of a few percent a year can, however, generate the observed home bias. Tesar and Werner (forthcoming) document that turnover ratios of foreign equities appear to be higher than those of domestic stocks, contradicting an explanation of home bias based on transaction costs. 
are less important for developing countries than for industrial countries. (Claessens, Dasgupta, and Glen; Buckberg; and Harvey also report this higher autocorrelation.)

Bekaert also observes, however, that global predictability has declined (comparing 1985-92 with the pre-1985 period). This complicates the interpretation of predictability through common factors as an indicator of market integration, and no clear pattern emerges on how predictability for individual emerging markets changes over time. Bekaert then also concludes that predictability per se does not yield much useful information about market segmentation. Instead, he calculates for each country the correlation between the fitted values of his expected-return equation for the United States with those for the other countries. This way he can control for the apparent decline in global predictability. $\mathrm{He}$ interprets this correlation as a measure of the degree of market integration across countries. (In a one-factor model, and if markets were perfectly integrated, expected returns would be perfectly correlated across markets.) Comparing the correlations for the two periods, he finds evidence of increased integration for most industrial countries and many emerging markets after 1985.

Tesar and Werner show that there is a significant "home bias" for developing countries. The cumulative inflow of foreign equity investments represents only a small fraction of stock market capitalization in the emerging markets and only a minute fraction of stock market capitalization in all industrial countries, much below any "optimal" share. Again, turnover ratios for foreign investment in emerging markets appear to be roughly of the same magnitude as, or somewhat lower than, those in the United States. Tesar and Werner document, however, that the share of recent U.S. outward equity investment going to emerging markets in total U.S. outward equity investment is in line with the share of the market capitalization of emerging markets in global capitalization. This suggests that at the margin the home bias has more recently disappeared.

In summary, most evidence based on asset prices suggests that emerging markets until the mid-1980s were not integrated with world financial markets but are now increasingly becoming integrated. Actual investment also provides evidence that emerging markets are becoming de facto integrated.

\section{The Role of Stock Markets and Benefits from Equity Investment FOR DEVELOPING COUNTRIES}

Efforts to improve the functioning of financial markets of developing countries, that is, to allocate capital more efficiently, have often focused on core financial themes such as interest liberalization, smaller government role in credit allocation, and improvement in the role of banks as financial intermediaries. (For a survey on the role of capital markets and the relation between stock market development and the functioning of financial intermediaries, see Demirgüç-Kunt and Levine 1993.) Recently, capital markets in general and stock markets in particular have received increased attention from policy- 
makers. Here I review the principal roles that stock markets can perform and relate some of the evidence the symposium articles provide of these roles.

\section{The Role of Stock Markets}

First, stock markets can be a vehicle for raising capital for firms. Although this is true for any other form of financial intermediation, stock markets may take on a larger role in developing countries where privatization and a greater role for the private sector imply a large demand for equity finance.

Second, capital markets in general, and equity markets in particular, can enable investors to diversify their wealth across a variety of assets, usually more easily than in most other financial markets. Thus, capital markets reduce the risk that investors must bear, thereby reducing the risk premium demanded and the cost of capital. The benefits of a lower risk premium can be particularly large in the case of foreign equity investment, because foreign investors are more diversified.

Third, stock markets can perform a screening and monitoring role. Relying on the information and judgment of numerous participants, stock prices quickly reflect changes in underlying values and indicate profitable investment opportunities, thus providing a screening and selecting function. Stock marketsthrough continuous adjustment of stock prices-can also assist in monitoring managers of publicly traded corporations, thereby possibly improving corporate governance. Foreign investment may be particularly useful because it introduces international practices and cross-country experiences. This monitoring role will take on increased importance as the number of publicly traded companies in developing countries increases.

Fourth, a financial system that functions well requires that the whole financial sector function efficiently. There can be important relations among the various financial institutions and complementarities from the point of view of capital suppliers and demanders. For example, the absence of a well-functioning stock market may limit the ability of firms to achieve an efficient mix of debt and equity, in spite of a well-functioning debt market. In this sense, stock markets and other financial intermediaries may function as complements, rather than substitutes, and a stock market that functions well may have positive externalities for the rest of the financial system.

These benefits of stock markets have to be balanced, however, against certain costs. Do stock markets perform these roles more efficiently than other financial intermediaries? This question becomes more important when there are some specific costs and concerns associated with stock markets that are not associated with other financial markets. Critics often claim that stock markets are nothing but casinos and that stock prices are not related to fundamentals. In general, stock markets in developing countries are often associated with volatility. Many policymakers are concerned that foreign flows may lead to excessive price movements and general macroeconomic instability (for example, real exchange rate 
variability). Thus some argue that stock markets contribute little to economic efficiency and may even be welfare-decreasing (for example, Stiglitz 1991).

\section{Evidence of Benefits}

The large foreign inflows in the past few years (table 1) document convincingly the ability of stock markets to raise foreign savings. Whether stock markets increase the overall mobilization of domestic resources-or are simply another vehicle for channeling the same amount of resources-is as of yet unclear. The experience of industrial countries suggests that in mature markets the net contribution of stock markets to firms' financing needs is small (see, for example, Mayer 1989). To date, firms in developing countries have relied to a greater extent on stock markets for their external finance than firms in industrial countries currently do (see Singh and others 1992 and Stiglitz 1993, table 1, p. 22). Whether this higher mobilization of resources will be sustained remains to be seen.

Concerning the risk-adjusted cost of capital, the benefits for developing countries are the mirror image of the benefits for an industrial-country investor. The test results reported by Bekaert, Buckberg, and Harvey show increased integration and thus indicate that the risk-adjusted cost of capital in emerging markets has moved more in line with that in industrial markets. This lower cost of capital associated with increased integration is also backed up by studies of individual securities' offerings. Tandon (1994) shows, for example, that offering bonds on the international markets leads to a reduction in the required rate of return of the same firm's equity. He finds a similar effect for the introduction of a country fund. In general, the increased foreign equity flows are part of a process that allocates global savings to the most productive investment, and this process leads not only to direct cost savings but also to higher investment and growth.

The static benefits of increased portfolio equity flows-the inflow of foreign resources and the lower risk-adjusted cost of capital-can thus be documented. The dynamic benefits of improved screening and monitoring and of externalities are more difficult to document. To some extent, there is an analogy here with the benefits of increased integration in trade. As has now been well documented, the static gains of increased trade are generally thought to be relatively small. Yet, much evidence shows that increased openness to trade and liberalization of prices is associated with increased overall economic growth, which suggests large dynamic gains. The exact channels through which these gains are realized are unclear, however.

A similar situation may exist with respect to foreign equity flows. Foreign investment-therewith bringing domestic asset prices in line with foreign prices-can lead to an improvement in the overall functioning of domestic financial markets and as a result lead to indirect economic efficiency and welfare gains. Although there is anecdotal evidence of these dynamic gains, evidence specific to foreign equity flows is scarce. 
Several articles in this issue provide evidence that emerging markets are not yet efficient, at least when compared with the (more thoroughly studied) markets of industrial countries. Return behavior, both on a cross-section and a timeseries basis, displays some patterns that raise questions about the effectiveness of the asset-allocation role played by the stock markets in the countries examined. For example, Claessens, Dasgupta, and Glen; Harvey; Buckberg; and Bekaert report that rates of return in many emerging markets have significant positive first-order autocorrelation, which indicates return predictability and possible inefficiencies. ${ }^{5}$ In industrial countries, by contrast, autocorrelations are generally insignificant. At the same time, Claessens, Dasgupta, and Glen document that emerging markets display few of the seasonal and cross-sectional anomalies found for industrial countries. Whether this means that the often institutionbased explanations used for the industrial countries do not transpose themselves to emerging markets or that the emerging markets are less or more efficient is still unclear at this point, however.

This evidence suggests that the emerging stock markets can still improve their functioning. Foreign capital can play a useful role in this respect as it may speed up domestic competition and stimulate innovation, thus leading to dynamic gains. Bekaert, for example, finds some evidence that opening up markets improves market efficiency. Diwan, Errunza, and Senbet (1993) show that country funds, despite their small size, can contribute to pricing efficiency and domestic resource mobilization.

Just as with trade in goods, countries may also find it more efficient to import some financial services rather than produce them domestically. Relying on foreign financial intermediaries and institutions may allow the country to avoid the cost of setting up expensive domestic financial infrastructure and to benefit from economies of scope and scale in international financial markets. The use of ADRs and direct listings on foreign stock exchanges are good examples of this "importation" of foreign financial skills, which can lead to cost savings. Eun, Claessens, and Jun (forthcoming) show that for a sample of Australian firms, for example, issuing an ADR reduced the cost of capital for the firm and possibly also for other firms in the same market. Bekaert (see next section) finds that a higher number of foreign-listed securities is associated with a higher degree of financial integration.

\section{Policy Issues for Developing Countries: Barriers and Volatility}

Two major policy issues for developing countries with emerging stock markets are barriers to integration and the volatility of equity (and other portfolio) flows.

5. Motivation for various types of time-series tests and results of actual tests for industrial countries can be found in Fama $(1970,1991)$. Harvey and Claessens, Dasgupta, and Glen also report that many of the emerging-market returns depart from normality. 


\section{Barriers}

The tests showing increased but still incomplete integration of emerging stock markets over time indicate that for both investors and firms in developing countries there still remain some unexploited gains from increased foreign investment. Whether these gains are attainable depends on whether barriers can be overcome or removed. Some barriers may be legal and may therefore be removed, if so chosen, easily; others are de facto and may limit foreigners' access to these markets for some time to come. Which are the most important barriers, and how can they be overcome or removed?

Bekaert identifies several barriers to equity flows in recipient countries and examines which barriers are effective by relating them to several measures of market integration. First, he finds that (macroeconomic) instability in the recipient country can be an important detriment: poor credit ratings, high and variable inflation, and exchange rate controls are barriers that have a high rankcorrelation with measures of lack of market integration. Second, the degree to which the domestic stock market is developed is an important factor: lack of a high-quality regulatory and accounting framework and the limited size of some stock markets are associated with a lower degree of integration. Claessens, Dasgupta, and Glen make the related point that emerging stock markets that function inefficiently may arise from exclusive access to information by certain firms or individuals-"insider trading." This would imply that the market will be stacked against "outsiders" and will be less likely to attract new investors, either foreign or domestic. Consequently, improvement in efficiency may in itself reduce a barrier. Finally, Bekaert finds that the de facto openness of the stock market matters: a lack of sufficient country funds or cross-listed securities or both is associated with lower integration. Surprisingly, Bekaert finds that formal barriers in the form of ownership restrictions seem to matter little, which suggests that these are not binding or are circumvented.

Hence, to further benefit, countries need to lower barriers. Some of these barriers obviously cannot be removed overnight. For example, a poor credit rating will remain a constraint on portfolio flows for some developing countries in the near future. But some other barriers may be easily removed. One conclusion from Bekaert's work is that countries wishing to attract portfolio flows would do best to list country funds and other securities internationally. Improving the way the stock market functions-investors often mention a malfunctioning stock market as a barrier-requires adopting improved investor protection safeguards, including disclosure requirements, accounting standards, and custody and settlement procedures. These safeguards can be adopted relatively easily, especially when relying on self-enforcing regulators, such as exchange houses and investment boards. Another example of a barrier that is relatively easy to remove is explored by Demirgüç-Kunt and Huizinga (forthcoming). They argue that by harmonizing the taxation of capital gains and dividends with the taxation of capital gains and dividends in industrial countries, emerging 
markets can enhance the effective returns to foreigners and lower their cost of capital. Ultimately, investors' perceptions and attitudes matter, too, and this makes it difficult to predict how any change in a given barrier will affect inflows. It is clear, however, that removing many of these barriers would be beneficial.

\section{Volatility}

For many developing countries that receive large portfolio flows, an important policy issue has been whether portfolio flows in general and equity flows in particular are volatile and potentially destabilizing to financial markets and the economy. Conventional wisdom is that short-term flows, and portfolio flows to developing countries in particular, are inherently unstable (see, for example, Reisen 1993). Many developing countries have actively tried to discourage short-term flows (through quantity constraints, taxes, or other instruments) or tried to encourage longer-term flows (for example, through subsidized foreign direct investment).

Claessens, Dooley, and Warner take issue with the conventional view that short-term flows are inherently more unstable and thus may require some policy action. Using data for five developing countries and five industrial countries, they show that there are no significant differences between the times-series properties of short-term flows and long-term flows. Put differently, if only timeseries (statistics) are used, it is not possible to tell the label of the flow. Claessens, Dooley, and Warner also show that because there is much substitution between the various flows, only an analysis of the aggregate capital account is meaningful. This implies that any capital control program or other policy (including subsidies and taxes) aimed at discouraging a particular type of flow because of its (alleged) volatile behavior may be misguided or ineffectual. Appropriate aggregate macropolicies aimed at achieving the desired overall capital account behavior are likely more effective in dealing with volatile flows. This is confirmed by Corbo and Hernandez (1994), who review the experience with capital inflows for nine countries and evaluate the various mechanisms used to manage these inflows. They conclude that aggregate demand measures (fiscal contractions) have been the most effective.

Tesar and Werner corroborate these findings. They investigate the time-series behavior of U.S. equity flows to emerging markets. They find little indication that countries with high U.S. investment activity have high rates of turnover (the volume of equity traded in relation to the local market capitalization). They also find no relation between U.S. flows and the volatility of stock returns. Kim and Singal (1993) and De Santis and Imrohoroglu (1994) investigate this issue as well. They both study the behavior of stock prices following the opening of a market to foreigners or large foreign inflows. They find that there is no systematic effect of liberalization on stock market volatility. These findings corroborate Bekaert's finding that volatility in emerging markets is unrelated to his measure of openness. Therefore the fear that foreign-market access will lead to more volatile domestic markets might be ill-founded. 


\section{CONCLUSION}

Equity portfolio flows can benefit developing countries by diversifying the sources of external finance, increasing the risk-bearing by investors, reducing the cost of capital, improving incentives for managing the investment process, assisting in the development of domestic capital markets, and enhancing the mobilization of domestic resources. Empirical evidence to date confirms some of these benefits. Several studies have found that emerging markets were not well integrated until the early $1980 \mathrm{~s}$. The corollary to the lack of integration has been that these markets have provided attractive investment and diversification opportunities for investors in industrial countries, which has likely motivated the larger inflows of foreign equity during the past few years. Now, as a result of increased equity flows and opening up, it is found that emerging markets are increasingly integrated with world financial markets, and this has brought their costs of capital more in line with those in world markets. To further reap these benefits, developing countries should (continue to) lower barriers to foreign equity flows. The most important barriers appear to be instability, underdeveloped stock markets, and a de facto lack of openness. Policy measures that can help remove these barriers are-in addition to proper fiscal and monetary policies-a solid regulatory and accounting framework, investor protection, and less restrictions on foreign ownership.

There is no empirical evidence to support the view that portfolio flows are more volatile than other types of capital flows or that they have a negative impact on stock price volatility. Therefore, the conventional wisdom that shortterm flows, and portfolio flows to developing countries in particular, are inherently unstable or destabilizing may be unfounded.

The research task ahead is still large, nevertheless. Important questions remain on the degree of capital-market integration, especially as it relates to different kinds of financial instruments (for example, are country funds better or worse than ADRs in this respect, and how about direct equity purchases?). Also, little is known on the specific benefits of foreign equity flows for improving corporate governance, and on the links between stock market development and the functioning of the whole financial system.

\section{REFERENCES}

The word "processed" describes informally reproduced works that may not be commonly available through library systems.

Adler, Michael, and Bernard Dumas. 1983. "International Portfolio Choice and Corporation Finance: A Synthesis." Journal of Finance 38(3):925-84.

Bank for International Settlements. 1993/1994. Annual Report. Basel, Switzerland.

Bekaert, Geert. 1995. "Market Integration and Investment Barriers in Emerging Equity Markets." The World Bank Economic Review 9(1):75-107.

Bekaert, Geert, and Campbell Harvey. 1994. "Time-varying World Market Integration." NBER Working Paper 4843. National Bureau of Economic Research, Cambridge, Mass. 
Buckberg, Elaine. 1993. "Emerging Stock Markets and International Asset Pricing." In Stijn Claessens and Sudarshan Gooptu, eds., Portfolio Investment in Developing Countries. World Bank Discussion Paper 228. Washington, D.C.

. 1995. "Emerging Stock Markets and International Asset Pricing." The World Bank Economic Review 9(1):51-74.

Calvo, Guillermo, Leonardo Leiderman, and Carmen Reinhart. 1993. "Capital Inflows and the Real Exchange Rate Appreciation in Latin America: The Role of External Factors." IMF Staff Papers 40(1):108-51.

Chuhan, Punam. 1994. "Are Institutional Investors an Important Source of Portfolio Investment in Emerging Markets?" wPs 1243. World Bank, International Economics Department, Washington, D.C. Processed.

Chuhan, Punam, Stijn Claessens, and Nlandu Mamingi. 1993. "Equity and Bond Flows to Latin America and Asia: The Role of Global and Country Factors." wPS 1160. World Bank, International Economics Department, Washington, D.C. Processed.

Claessens, Stijn, and Sudarshan Gooptu, eds. 1993. Portfolio Investment in Developing Countries. World Bank Discussion Paper 228. Washington, D.C.: World Bank.

Claessens, Stijn, and Moon-Whoan Rhee. 1994. "The Effect of Equity Barriers on Foreign Investment in Developing Countries." In Jeffrey Frankel, ed., Internationalization of Equity Markets. Chicago, Mll.: University of Chicago Press.

Claessens, Stijn, Susmita Dasgupta, and Jack Glen. 1995. "Return Behavior in Emerging Stock Markets." The World Bank Economic Review 9(1):131-52.

Claessens, Stijn, Michael Dooley, and Andrew Warner. 1995. "Portfolio Flows: Hot or Cold." The World Bank Economic Review 9(1):153-74.

Cooper, Ian, and Evi Kaplanis, 1991. "What Explains the Home Bias in Portfolio Investment?" Discussion Paper IfA-136-91. London Business School, Institute of Finance and Accounting, London. Processed.

Corbo, Vittorio, and Leonardo Hernandez. 1994. "Macroeconomic Adjustment to Capital Inflows: Latin American Style versus East Asian Style." wps 1377. World Bank, International Economics Department, Washington, D.C. Processed.

Demirgüç-Kunt, Asli, and Ross Levine. 1993. "Stock Market Development and Financial Intermediary Growth." wPs 1159. World Bank, Policy Research Department, Washington, D.C. Processed.

Demirgüç-Kunt, Asli, and Harry Huizinga. Forthcoming. "Barriers to Portfolio Investments in Emerging Stock Markets." Journal of Development Economics.

De Santis, Giorgio. 1993. "Asset Pricing and Portfolio Diversification: Evidence from Emerging Financial Markets.” In Stijn Claessens and Sudarshan Gooptu, eds., Portfolio Investment in Developing Countries. World Bank Discussion Paper 228. Washington, D.C.

De Santis, Giorgio, and Selahattin Imrohoroglu. 1994. "Stock Returns and Volatility in Emerging Financial Markets." University of Southern California, Department of Finance and Business Economics, Los Angeles, Calif. Processed.

Divecha, Arjun, Jaime Drach, and Dan Stefak. 1992. "Emerging Markets: A Quantitative Perspective." Journal of Portfolio Management 19(Fall):41-50.

Diwan, Ishac, Vihang Errunza, and Lemma Senbet. 1993. "Country Funds for Emerging Economies." In Stijn Claessens and Sudarshan Gooptu, eds., Portfolio Investment in Developing Countries. World Bank Discussion Paper 228. Washington, D.C. 
Dooley, Michael, Eduardo Fernandez-Arias, and Kenneth Kletzer. 1994. "Is the Debt Crisis History? Recent Private Capital Inflows to Developing Countries." wPs 1327. World Bank, International Economics Department, Washington, D.C. Processed.

Dumas, Bernard. 1994. "Partial-Equilibrium versus General-Equilibrium Models of the International Capital Market." In Frederick van der Ploeg, ed., Handbook of International Economics. Oxford, U.K.: Basil Blackwell.

Dumas, Bernard, and Bruno Solnik. 1993. "The World Price of Exchange Rate Risk." NBER Working Paper 4459. National Bureau of Economic Research, Cambridge, Mass.

Eun, Cheol, Stijn Claessens, and Kwang Jun. Forthcoming. "International Trade of Assets, Pricing Externalities, and the Cost of Capital." Pacific-Basin Finance Journal $3(1)$.

Fama, Eugene. 1970. "Efficient Capital Markets: A Review of Theory and Empirical Work." Journal of Finance 25(2):383-417.

__. 1991. "Efficient Capital Markets: II." Journal of Finance 46(5):1575-1617.

Fernandez-Arias, Eduardo. 1994. "The New Wave of Private Capital Inflows: Push or Pull?” WPS 1312. World Bank, International Economics Department, Washington, D.C. Processed.

Ferson, Wayne, and Campbell Harvey. 1993. "The Risk and Predictability of International Equity Returns." Review of Financial Studies 6(3):527-66.

French, Kenneth R., and James M. Poterba. 1991. "Investor Diversification and International Equity Markets." American Economic Review 81(2, May):222-26.

Gooptu, Sudarshan. 1993. "Portfolio Investment Flows to Emerging Markets." In Stijn Claessens and Sudarshan Gooptu, eds., Portfolio Investment in Developing Countries. World Bank Discussion Paper 228. Washington, D.C.

Harvey, Campbell. 1991. "The World Price of Covariance Risks." Journal of Finance 46(4):111-57.

_- 1993. "Portfolio Enhancement Using Emerging Markets and Conditioning Information." In Stijn Claessens and Sudarshan Gooptu, eds., Portfolio Investment in Developing Countries. World Bank Discussion Paper 228. Washington, D.C.

- 1994. "Predictable Risk and Returns in Emerging Markets." Working Paper. Duke University, Fuqua School of Business, Durham, N.C. Processed.

—_ 1995. "The Risk Exposure of Emerging Equity Markets." The World Bank Economic Review 9(1):19-50.

IFC (International Finance Corporation). Various years. Emerging Stock Markets Factbook. Washington, D.C.

Kim, E. Han, and Vijay Singal. 1993. "Opening Up of Stock Markets by Emerging Economies: Effect on Portfolio Flows and Volatility of Stock Prices." In Stijn Claessens and Sudarshan Gooptu, eds., Portfolio Investment in Developing Countries. World Bank Discussion Paper 228. Washington, D.C.

Mayer, Colin. 1989. "Myths of the West: Lesson from Developed Countries for Development Finance." wPs 301. World Bank, Office of the Vice President, Development Economics, Washington, D.C. Processed.

Reisen, H. 1993. "The Case for Sterilized Intervention in Latin America." Paper presented at the 6th Annual Inter-American Seminar on Economics, May 28-29, Caracas, Venezuela. 
Singh, Ajit, Javed Hamid, Bahram Salimi, and Yoicki Nakano. 1992. "Corporate Financial Structures in Developing Countries." Technical Paper No. 1. International Finance Corporation, Washington, D.C. Processed.

Solnik, Bruno. 1974. "An Equilibrium Model of the International Capital Markets." Journal of Economic Theory 8(4):500-24.

Stiglitz, Joseph. 1991. "Government, Financial Markets, and Economic Development." NBER Working Paper 3669. National Bureau of Economic Research, Cambridge, Mass.

- 1993. "The Role of the State in Financial Markets." In Proceedings of the World Bank Annual Conference on Development Economics 1993. Washington, D.C.: World Bank.

Stulz, René M. 1994. "International Portfolio Choice and Asset Pricing: An Integrative Survey." NBER Working Paper 4645. National Bureau of Economic Research. Cambridge, Mass.

Tandon, Kishore. 1994. "External Financing in Emerging Economies: An Analysis of Market Responses." World Bank, International Economics Department, Washington, D.C. Processed.

Tesar, Linda, and Ingrid Werner. 1995. "U.S. Equity Investment in Emerging Stock Markets." The World Bank Economic Review 9(1):109-30.

- Forthcoming. "Home Bias and High Turnover." Journal of International Money and Finance.

World Bank. 1993. World Debt Tables 1993-94. Washington, D.C. 